\title{
PENYULUHAN DAN PELATIHAN PEMBUATAN COOKIES TIWUL DAN KERUPUK TIWUL DI KWT KENANGA DS SUKAJAWA, KECAMATAN BUMI RATU NUBAN, KABUPATEN LAMPUNG TENGAH
}

\author{
Fibra Nurainy*, Sri Hidayati, Dyah Koesoemawardani, Erdi Suroso, Teguh Setiawan \\ Jurusan Teknik Hasil Pertanian Fakultas pertanian Universitas Lampung, Bandar Lampung \\ Jl. Prof. Sumantri Brojonegoro No.1 Bandar Lampung 35145 \\ Penulis Korespodensi : fibranurainy@gmail.com
}

\begin{abstract}
Abstrak
Kelompok Wanita Tani (KWT) Kenanga yang berada di Kecamatan Bumi Ratu Nuban merupakan KWT yang melalukan usaha diversifikasi produk singkong. Produk KWT Kenanga saat ini adalah Tiwul kering yang dikemas dan selanjutnya dijual di pasaran. Pada produksi tiwul terdapat tiwul yang berbentuk butiran halus yang tidak memenuhi kriteria untuk dijual disebut sebagai tiwul afkir (off grade). Untuk meningkatkan nilai jual dan nilai ekonomi tiwul afkir perlu dilakukan diversifikasi produk. Pada kesempatan ini dilakukan penyuluhan dan pelatihan pembuatan cookies tiwul dan kerupuk tiwul. Beberapa permasalahan yang ditemukan adalah a).produk diversifikasi produk tiwul masih terbatas jenisnya, b) mitra belum menguasai teknologi pengolahan cookies tiwul dan kerupuk tiwul, c). mitra belum menguasai pengetahuan tentang kemasan dan pelabelan produk makanan. Solusi yang ditawarkan untuk mengatasi masalah tersebut adalah 1). melakukan penyuluhan dan pelatihan tentang teknologi diversifikasi produk tiwul 2). membantu memperbaiki sistem kemasan, pelabelan dan pemasaran, 3). Pemberian fasilitas peralatan untuk mendukung usaha diversifikasi produk berbasis tiwul. Tujuan yang ingin dicapai dari kegiatan ini adalah terciptanya KWT yang tangguh dan tanggap dengan perkembangan teknologi dan tuntutan konsumen akan jenis dan kualitas produk yang dihasilkan, teraplikasikannya teknologi diversifikasi tiwul sehingga tercapai nilai tambah produk yang diinginkan, terwujudnya jejaring pasar yang luas dan sistem pemasaran dan promosi yang lebih baik serta terbukanya peluang kerja baru serta terciptanya sinergi antara perguruan tinggi dengan dunia usaha. Hasil pengabdian menunjukkan bahwa mitra sangat antusias dengan kegiatan pengabdian ini ditunjukkan dengan semangat peserta dalam mengikuti kegiatan penyuluhan, praktek dan mengaplikasikan praktek. Kegiatan penyuluhan yang dilakukan dalam kegiatan pengabdian ini dapat meningkatkan pengetahuan peserta mengenai pengolahan tiwul dan diversifikasi produk tiwul dari nilai rata-rata 50 menjadi 80. Hasil penyuluhan dan pelatihan selanjutnya dipraktekkan dan dikembangkan secara mandiri oleh mitra sehingga untuk cookies tiwul sudah mendapat tempat pemasaran di salah satu swalayan di Lampung Tengah.
\end{abstract}

Kata kunci: Tiwul afkir, cookies, kerupuk

\section{Pendahuluan}

Lampung Tengah adalah wilayah dengan komoditas penghasil singkong terbesar di Indonesia dengan luas 79.805 hektare dan produksi 2,4 juta ton atau setara dengan 40.20 persen dari total produksi ubikayu di Provinsi Lampung. Kecamatan Bumi Ratu Nuban dan kecamatan Bekri berada di wilayah Kabupaten Lampung Tengah yang memiliki lahan untuk ubi kayu seluas 720 ha dan 2.303 ha dengan produksi ubi kayu pada tahun 2014 sebesar 52.300 ton dan 17.470 ton ( BPS Lampung Tengah 2015)
Ubikayu memiliki sifat bahan baku yang bulky dan perishable sehingga mengharuskan ubikayu untuk dibuat dan diperdagangkan dalam bentuk kering atau produk antara seperti gaplek atau chips ( FAO, 2011). Salah satu faktor penting dalam mensukseskan program keanekaragaman pangan adalah pengembangan produk yang praktis, kalau digunakan tidak bersisa dan mudah diperoleh. Bentuk makanan yang siap olah dan siap santap merupakan pilihan yang terbaik (Baharsyah , 1994). Utami et al (2012) menyatakan bahwa pangan lokal ubikayu memiliki potensi dan peluang bisnis jika diolah sesuai dengan ekspektasi selera 
konsumen. Salah satu upaya untuk meningkatkan daya awet dan meningkatkan nilai tambah pada ubi kayu adalah mengolah menjadi tiwul . Kandungan nutrisi nasi tiwul di masing-masing 100 gram bahan baku (singkong) yaitu: Mengandung 63. 50 gram air, Fospor sejumlah 40 gram, Karbohidrat 35 gram, Kalsium $33 \mathrm{mg}$, Vitamin C $30 \mathrm{mg}$, Protein 1. $20 \mathrm{mg}$, Zat besi $0.70 \mathrm{mg}$, Lemak $0.30 \mathrm{mg}$, Vitamin B1 0. $01 \mathrm{mg}$, dan kalori $(121 \mathrm{kal})$ (Hidayat, dkk., 2016).

KWT Kenanga mengolah ubikayu menjadi tiwul. Pada proses penggranulan tiwul tidak semua tiwul menjadi granul dengan ukuran yang memenuhi kriteria, tetapi terdapat tiwul afkir yang meiliki ukuran butiran sangat halus sehingga disebut tiwul afkir. Tiwul afkir tidak dapt dijual sebagai tiwul, sehingga nilai ekonominya sangat rendah. Untuk mengatasi hal tersebut perlu dilakukan diversifikasi produk tiwul menjadi makanan lain berbasis tiwul. Produk tiwul yang sudah dibuat di KWT Kenanga yang berbahan dasar tiwuk afkir antara lain bipang tiwul dan snack balado tiwul. Dalam setiap produksi tiwul dihasilkan sekitar $20 \%$ tiwul afkir.

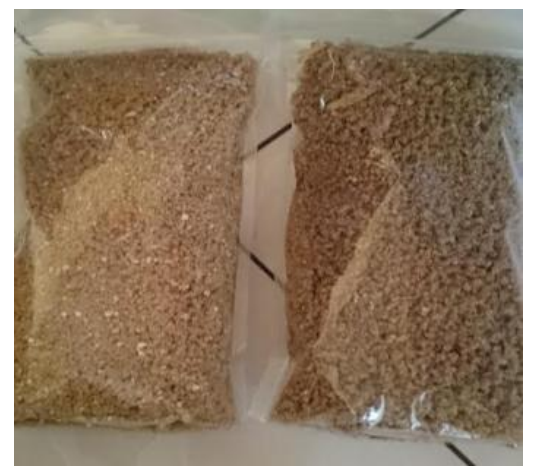

Gambar 1. Tiwul afkir, butiran halus( kiri), Tiwul (kanan)

Tiwul afkir tidak bisa dijual atau bila dijual memiliki nilai ekonomi yang rendah. Oleh karena itu perlu diupayakan pemanfaatan tiwul afkir menjadi produk lain yang bernilai jual lebih tinggi. Beberapa permasalahan yang ditemukan adalah a).produk diversifikasi produk tiwul masih terbatas jenisnya, b) mitra belum menguasai teknologi pengolahan cookies tiwul dan kerupuk tiwul, c). mitra belum menguasai pengetahuan tentang kemasan dan pelabelan produk makanan . Solusi yang ditawarkan untuk mengatasi masalah tersebut adalah 1). melakukan penyuluhan dan pelatihan tentang teknologi diversifikasi produk tiwul 2). membantu memperbaiki sistem kemasan, pelabelan dan pemasaran, 3). Pemberian fasilitas peralatan untuk mendukung usaha diversifikasi produk berbasis tiwul.

\section{Bahan dan Metode}

\section{A. Bahan dan Alat}

Bahan yang digunakan dalam kegiatan ini meliputi tiwul afkir, tapioka, bahan pembuat cookie seperti margarine, gula halus, tepung terigu, choco chips dan lain-lain. Alat yang diperlukan adalah mixer, loyang, oven, tampah, kukusan dan lain-lain.

\section{B. Metode Pelaksanan}

Pelaksanaan kegiatan meliputi dua tahap yaitu survey awal dan kegiatan inti ( penyuluhan dan pelatihan).

a. Survei Tempat dan Kondisi Masyarakat Sasaran

Survei memiliki tujuan untuk mengidentifikasi tempat dan keadaan masyarakat sasaran. Pada kegiatan ini tim pengabdian melakukan survei langsung ke lokasi mitra. Pada saat survei dilakukan wawancara yang merupakan interaksi awal terhadap masyarakat calon mitra untuk mendapatkan data informasi serta kendala yang dihadapi oleh calon kelompok mitra. Melalui kegiatan ini digali masalah-masalah yang ada pada usaha produksi calon mitra , kemudian bersama-sama dengan calon mitra merumuskan masalah yang ingin diselesaikan melalui program pengabdian .

\section{b. Kegiatan penyuluhan dan pelatihan}

Proses penyuluhan dilaksanakan dengan mengedepankan metode sharing informasi dengan masyarakat mitra binaan. Peserta dibimbing untuk mengenal dan memahami diversifikasi olahan tiwul dan juga tentang pengemasan serta pelabelan produk pangan. Peserta juga diberi kesempatan untuk melakukan praktek pembutan diversifikasi olahan tiwul yaitu cookie tiwul dan kerupuk tiwul, sehingga peserta dapat lebih memahami cara pengolahannya dan walaupun kegiatan telah usai peserta dapat melakukan sendiri dan meiliki inisiatif untuk pengembangan produk. Untuk mengetahui tingkat pemahaman peserta juga dilakukan pre tes dan post tes. 


\section{Hasil dan Pembahasan}

A. Survey Awal

Kegiatan survey dilakukan untuk mengetahui kondisi mitra terkini. Survey awal dilakukan pada hari Rabu, tanggal 20 Agustus 2019. Hasil survey ke lokasi mitra menunjukkan bahwa produk diversifikasi tiwul afkir belum banyak variasi. Dari pantauan tim pengabdian ada dua jenis produk diversifikasi yang diusahakan mitra, yaitu bipang dan snack tiwul. Oleh karena itu perlu dilakukan variasi produk yang lain.

\section{B. Penyuluhan dan Pelatihan Pengolahan Tiwul dan Diversifikasi Produk Tiwul}

Kegiatan penyuluhan dan pelatihan pengolahan tiwul dan diversifikasi produk tiwul dilakukan pada hari Rabu tanggal 4 September 2019. Kegiatan dihadiri 12 anggota KWT Kenanga, bertempat di rumah ketua KWT Kenanga ibu Solekhah berlangsung dari pukul 10.00 - 16.00. Kegiatan diawali dengan post tes mengenai pembuatan cookies dan kerupuk tiwul. Hasil pre tes menunjukkan bahwa pemahaman peserta masih rendah, yaitu rata-rata 50 .

Acara selanjutnya adalah penyuluhan yang diberikan oleh :

1. Dr. Sri Hidayati,M.P mengenai proses pengolahan tiwul dan mutu tiwul yng baik

2. Ir. Fibra Nurainy, M.T.A mengenai diversifikasi Olahan Tiwul

3. Dyah Koesoemawardani,S.Pi.M.P. mengenai Pengemasan produk olahan tiwul

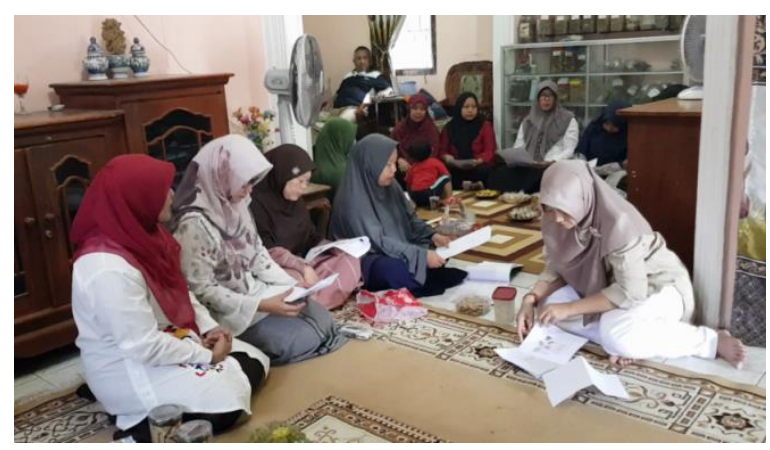

Gambar 2. Penyuluhan oleh Dr Sri Hidayati, M.P

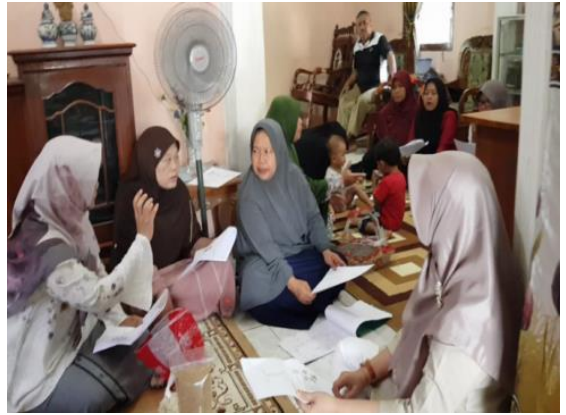

Gambar 3. Penyuluhan oleh Ir. Fibra Nurainy

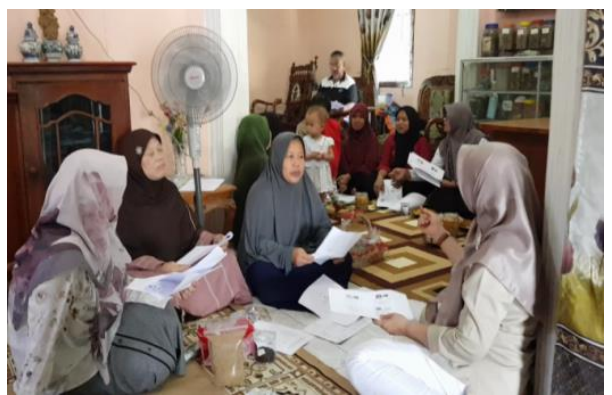

Gambar 4 . Penyuluhan oleh Dyah Koesoemawardani, M.P.

Setelah penyuluhan dilakukan post tes kembali dengan soal yang sama pada saat pre tes. Hasil Pre tes menunjukan peningkatan skor nilai test menjadi 80. Acara Penyuluhan diakhiri sekitar pukul 12.00 yang merupakan waktu untuk istirahat, sholat dan makan siang.

Kegiatan praktek pembuatan diversifikasi olahan tiwul dilanjutkan setelah istirahat, dimulai dari pukul 13.00. Pada kegiatan ini dilakukan pembuatan krupuk dan cookies Seluruh peserta dilibatkan secara aktif pada kegiatan praktek, sehingga semuanya dapat memahami dan melakukan proses pengolahan kerupuk tiwul dan cookies tiwul .

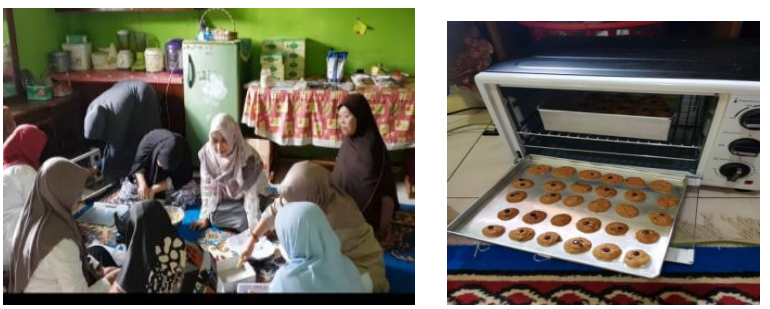

Gambar 5. Praktek pembuatan cookies tiwul 

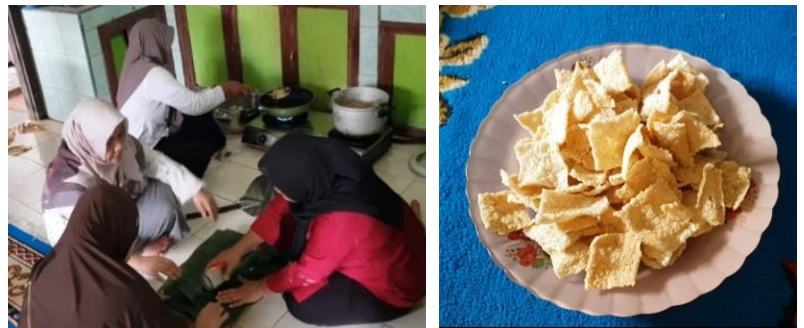

Gambar 6. Praktek pembuatan krupuk tiwul

\section{Pemantauan Hasil Kegiatan}

Pemantauan kegiatan dilakukan tujuh hari setelah kegiatan penyuluhan dan pelatihan. Hasil pemantauan menunjukkan bahwa mitra mempunyai semangat yang tinggi untuk mencoba produk diversifikasi tiwul. Produk cookies tiwul sudah dibuat oleh KWT Kenanga dengan hasil seperti yang disajikan pada Gambar. Cookies tiwul sedang dalam proses upaya untuk dapat dipasarkan di supermarket di daerah Lampung Tengah.
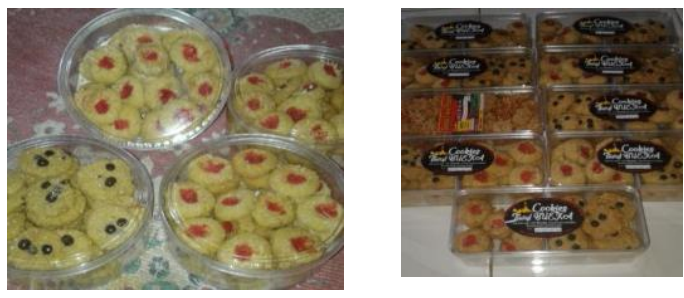

Gambar 7. Hasil karya mitra setelah kegiatan penyuluhan dan praktek diversifikasi olahan tiwul.

\section{Kesimpulan}

Hasil pengabdian menunjukkan bahwa mitra sangat antusias dengan kegiatan pengabdian ini ditunjukkan dengan semangat peserta dalam mengikuti kegiatan penyuluhan, praktek dan mengaplikasikan praktek . Kegiatan penyuluhan yang dilakukan dalam kegiatan pengabdian ini dapat meningkatkan pengetahuan peserta mengenai pengolahan tiwul dan diversifikasi produk tiwul dari nilai rata-rata 50 menjadi 80 . Hasil penyuluhan dan pelatihan selanjutnya dipraktekkan dan dikembangkan secara mandiri oleh mitra sehingga untuk cookies tiwul sudah mendapat tempat pemasaran di salah satu swalayan di Lampung Tengah.

\section{Ucapan Terima Kasih}

Ucapan terimakasih diberikan kepada Universitas Lampung dan LPPM Universitas Lampung yang telah mendanai dan memfasilitasi kegiatan pengabdian ini melalui skim Pengabdian Unggulan 2019.

\section{Daftar Pustaka}

BPS Lampung Tengah.2015. Lampung tengah Dalam Angka. Badan Pusat Statistik Lampung Tengah.

Baharsyah, S. 1994. Diversifikasi Pangan Melalui Product Development. Majalah Pangan No. 18, Vol. V. Jakarta.

FAO. 2011. The cassava transformation in Africa". The Food and Agriculture Organization of the United Nations (FAO).Hidayat, B. 2016. Prospek Pengembangan dan Teknologi Pengolahan Beras Siger. ISBN 978-602-70530-3-8. UP Politeknik Negeri Lampung.

Hidayat, B., Syamsu Akmal, Surfiana, dan B. Suhada. 2016. Beras Siger (Tiwul/Oyek yang Telah Dimodernisasi) sebagai Pangan Fungsional dengan Kandungan Indeks Glikemik Rendah. Seminar Nasional Pangan Fungsional dalam Rangka Memperingati Hari Tempe Sedunia. Bandar Lampung, 28Mei 2016.

Hidayat, B., Yatim Rahayu W., dan Hertini Rani. 2012. Kajian Ilmiah Peningkatan Kualitas Tiwul Tradisional. Kontrak Nomor 800/893.1/II.05/2012. Badan Ketahanan Pangan Daerah Provinsi Lampung.http://www.suara.com, 2016). Garagara Singkong, Bupati Lampung Tengah Curhat ke Jokowi .

Utami , P, dan Budiningsih, S. 2014. Diversifikasi Olahan Pangan Lokal Ubikayu dan Teknologi Pengolahannya Pada Tingkat Rumah Tangga Pedesaan Dalam Rangka Ketahanan Pangan. Prosiding Seminar Hasil Penelitian LPPM UMP 2014 ISBN 978-602-14930-2-1 Purwokerto, 6 September 2014 